\title{
A Better, Dual Theory of Human Rights
}

Marcus Arvan

(Marvan@ut.edu)

Human rights theory and practice are stuck in a rut. Although disagreement is normal in philosophy and social-political practice, the depth and breadth of disagreement about human rights in theory and practice is unusual. As James Griffin and Charles Beitz point out, respectively:

The term 'human right' is nearly criterionless. There are unusually few criteria for determining when the term is used correctly and when incorrectly - and not just among politicians, but among philosophers, political theories, and jurisprudents as well. ${ }^{1}$

[A]lthough the idea and language of human rights have become increasingly prominent in public discourse, it has not become any more clear what kinds of objects human rights are supposed to be, why we should believe that people have them, or what follows from this belief for political practice...[This is] a problem for anyone inclined to believe that our political ideas should have some clear and distinct significance in our thinking about how to act. This is especially so when the ideas play such a central role in framing public concerns of great importance. ${ }^{2}$

Indeed, there is radical disagreement on just about everything about human rights, including:

- What they are (i.e. what their practical or metaphysical nature is).

- How many of them there are.

- What they are for (what role they should play in moral, social, and political practice).

- What human interests or capacities they are supposed to protect.

${ }^{1} \mathrm{~J}$. Griffin, On human rights (Oxford: Oxford University Press, 2007): 14-15.

${ }^{2}$ C. Beitz, The idea of human rights (Oxford: Oxford University Press, 2009): xi-xii. 
- What kinds of duties they impose.

- Who they impose those duties upon.

- Etc.

Consider first the question of what human rights are. Many have argued that human rights are, by definition, whichever moral rights all human beings have "simply in virtue of being human" - that is, they are "timeless" rights human beings would have outside of any society at all, in a "state of nature." ${ }^{3}$ Others, however, contend that human rights are socially constructed standards for evaluating domestic and international social-political systems, and so are not "timeless." ${ }^{4}$ Finally, others argue that human rights are political standards of a very specific sort: rights that delineate when human beings are morally entitled to coercive international intervention. ${ }^{5}$

Next, consider how many human rights there are. Here, the level of disagreement explodes. Some human rights "minimalists" argue that there are just a handful of human rights - specifically, rights to life, subsistence, property, and freedom from slavery and serfdom. ${ }^{6}$ Others argue that there are a moderate number of human rights, but not as many as those contained in the Universal Declaration of Human Rights (UDHR) or existing human rights covenants. ${ }^{7}$ Others argue that there are many more human rights, and that the UDHR and

\footnotetext{
${ }^{3}$ Griffin (2007): 2; J. Nickel, Making sense of human rights. 2nd ed. (Malden, MA: Blackwell Publishing, 2007); and J. Tasioulas, "Human rights, universality and the values of personhood: retracing Griffin's steps." European Journal of Philosophy, 10(1), (2002): 79-100.

4 J. Donnelly, Universal Human Rights in Theory and Practice, $2^{\text {nd }}$ ed. (Ithaca, NY: Cornell University Press, 2003); Beitz (2009); and J. Raz, "Human rights without foundations." In J. Tasioulas \& S. Besson (eds.), The Philosphy of International Law (Oxford University Press, 2010).

${ }^{5}$ J. Rawls 1999. The Law of Peoples: with, "The Idea of Public Reason Revisited" (Cambridge, MA: Harvard University Press, 1999). Also see J, Tasioulas, "Are Human Rights Essentially Triggers for Intervention?" Philosophy Compass 4(6), (2009): 938-50, for an overview.

${ }^{6}$ Rawls (1999); S. Freeman, "The Law of Peoples, Social Cooperation, Human Rights, and Distributive Justice." Social Philosophy and Policy 23(1), (2006): 29-68; and D. Reidy, "Rawls on international justice: A defense." Political Theory 32, no. 3 (2004): 291-319.

${ }^{7}$ See Griffin (2007): chs 8-11.
} 
existing human rights covenants contain more or less the correct list and number. ${ }^{8}$ Others still argue that there are human rights to basically all liberal-democratic rights - including, centrally, a right to democratic elections. ${ }^{9}$ Finally, others still argue that there are human rights to just about every good thing under the sun, including rights to love, sexual pleasure, a clean environment, and meaningful work. ${ }^{10}$

Next, consider the question of what human rights are for - that is, what their moral, social, and political functions are. Many have argued that human are "minimal" international standards that define the limits of morally legitimate governance. ${ }^{11}$ Along this vein, some have argued that the principal function of human rights is to justify coercive international intervention when they are violated, up to and including military force. ${ }^{12}$ Others, however, argue that some human rights are minimal international standards whereas others are standards for aspiration or "good government."13

Next, consider the question of which kinds of duties human rights impose, and upon which agents those duties fall. Some argue that the international community is under a collective duty to coercively enforce human rights standards. ${ }^{14}$ Others hold that duties to enforce human rights fall primarily, if not exclusively, on nation-states within their own

\footnotetext{
8 Donnelly (2003), Nickel (2007), Beitz (2009).

${ }^{9}$ S. Caney, Justice beyond borders: A global political theory (Oxford: Oxford University Press, 2005): 78-85.

${ }^{10}$ See M.D. Pendleton, "A New Human Right - The Right to Globalization", Fordham International Law Journal, 22 June (1999): 2052; J. Galtung and A. H. Wirak, "Human Needs and Human Rights-A Theoretical Approach." Security Dialogue 8.3 (1977): 251-258. Also see "Sexual Rights are Fundamental and Universal Human Rights", http://www.tc.umn.edu/ colem001/was/wdeclara.htm (accessed June 16, 2013) and Draft Declaration of Human Rights and the Environment (http://www.tc.umn.edu/ colem001/was/wdeclara.htm: accessed June 16, 2013). Cf. Raz (2010).

11 A. Buchanan, Justice, legitimacy, and self-determination (Oxford: Oxford University Press, 2004); D. Miller, National responsibility and global justice (Oxford: Oxford University Press, 2007); Nickel (2007); Rawls (1999); H. Shue, Basic rights: Subsistence, affluence, and US Foreign policy. 2nd ed. (Princeton, NJ: Princeton University Press, 1996).

12 Rawls (1999).

${ }^{13}$ Beitz (2009), Donnelly (2003), Nickel (2007): 101, and Raz (2010).

${ }^{14}$ M. Cranston, What are human rights? Revised ed. (London: Bodley Head, 1973).
} 
borders. $^{15}$ Others still, however, hold that human rights sometimes justify coercive international enforcement, but sometimes justify only non-coercive international promotion, depending on which human rights are at issue ${ }^{16}$ (though it is rarely made very clear when or why ${ }^{17}$ ). Still others, however, hold that human rights need not be enforced by anyone, but must at least impose determinate duties on determinate addressees. ${ }^{18}$ And others still hold that they need not even impose determinate duties on anyone, but rather merely provide pro tanto reasons to act. 19

Finally, consider the question of which values, human interests, or capacities human rights are supposed to protect. Human rights have been claimed to be protections of:

- Fundamental human interests ${ }^{20}$

- $\quad$ Basic needs ${ }^{21}$

- Urgent human interests ${ }^{22}$

- Central human capabilities ${ }^{23}$

- Agency $^{24}$

- Autonomy $^{25}$

- $\quad$ Liberty $^{26}$

- $\quad$ Freedom and equality ${ }^{27}$

\footnotetext{
${ }^{15}$ Donnelly (2003): chapters 8-10.

${ }^{16}$ Beitz (2009): 106-25, Griffin (2007): 101-3, Miller (2007): 46-8, and Nickel (2007): 101.

17 M. Arvan, "Reconceptualizing Human Rights." Journal of Global Ethics 8(1), (2012): 91-105.

18 0. O’Neill, "The dark side of human rights." International Affairs 81 (2005): 427-39.

${ }^{19}$ Beitz (2009). Cf. Raz (2010).

${ }^{20}$ Rawls (1999)

${ }^{21}$ Miller (2007): 179-181.

22 Beitz (2009).

${ }^{23}$ A. Sen, Commodities and capabilities (Amsterdam: North Holland, 1985); A. Sen, "Capability and well-being", in The quality of life, eds. M. Nussbaum and A. Sen (Oxford: Clarendon Press, 1993): 30-53; M. Nussbaum, Women and human development: the capabilities approach (Oxford: Clarendon Press, 2000).

${ }^{24}$ A. Gewirth, Human rights (Chicago, IL: University of Chicago Press, 1984).

${ }^{25}$ Griffin (2007), Shue (1996).

${ }^{26}$ Griffin (2007).
} 
- Human dignity ${ }^{28}$

- A minimally decent human life 29

- $\quad$ Justice 30

Worse, many of these notions seem essentially contestable, or open to radically different interpretations (What are "fundamental human interests"? What are "urgent" ones? What is a "minimally decent human life"? Who is to decide?). ${ }^{31}$

These disagreements spill into human rights practice in pernicious ways. First, public skepticism about human rights is common. A recent study of the American public found, for example, that although $80 \%$ of the American public believes that "every person has basic rights" 32 , a full 55\% of respondents also agreed that, "because of different cultures and values, it is impossible to have rights that apply to everyone in the world."33 Given that human rights are understood in the UDHR and existing human rights covenants as rights that apply universally to all human beings, this means that $55 \%$ of American respondents in effect deny the existence of human rights, at least as human rights are understood in official human rights documents and treaties. Moreover, in the same study, significant proportions of the American public reported disagreeing with a number of specific provisions contained in the UDHR. For example, Article 25 of the UDHR asserts a human right to freedom from severe poverty, including a right to adequate housing. However, only 48\% of Americans in the aforementioned study reported disagreeing with the claim that there is a human right to freedom from severe

\footnotetext{
27 Donnelly (2003), Caney (2005).

${ }^{28}$ Donnelly (2003).

${ }^{29}$ Buchanan (2004), Nickel (2007), Miller (2007), and many others.

${ }^{30}$ Caney (2005), A. Clapham, Human rights: A very short introduction (Oxford: Oxford University Press, 2007).

${ }^{31}$ See Arvan (2012): 99-102.

32 "Human Rights in the U.S.: Opinion Research with Advocates, Journalists, and the General Public", http://opportunityagenda.org/pdfs/HUMAN\%20RIGHTS\%20REPORT.PDF (accessed June 25, 2013): p. 3.

33 Ibid: 6, italics added.
} 
poverty, and $49 \%$ surveyed disagreed with the claim that there is a right to adequate housing. ${ }^{34}$ Second, human rights claims in the UDHR and existing covenants have been consistently met with accusations of Western moral and cultural imperialism. Islamic and Asian commentators, for example, have consistently objected to the fact that the UDHR and existing human rights covenants embody a distinctly Western moral ideal of freedom and equality - an ideal that these commentators to be inconsistent with Islamic and Asian ethical value systems. ${ }^{35}$ Moreover, as Jack Donnelly shows, the UDHR and existing human rights covenants clearly do embody distinctly Western norms of freedom and equality. ${ }^{36}$ For example, many of the rights asserted in the UDHR - e.g., that people have human rights to equality before the law (Article 7) and equal rights in marriage (Article 16) - are nowhere to be found in the Cairo Declaration of Human Rights, an Islam-based human rights document which in turn asserts a number of rights found nowhere in the UDHR. ${ }^{37}$ Although many human rights theorists have attempted to defend the UDHR and existing human rights covenants against these complaints - arguing, typically, that human freedom and equality is becoming increasingly seen internationally as necessary for protection of human dignity 38 or "urgent human interests"39 - a significant number of Western human rights theorists actually agree with the accusation that existing human rights standards are unacceptably Western and liberal in nature..$^{40}$

The sheer depth and breadth of theoretical and public disagreement about human rights raises the obvious question: what is the root cause of these problems? In an earlier

\footnotetext{
34 Ibid: 4.

35 See Beitz (2009, 4-7) and M. Ignatieff, Human rights as politics and idolatry (Princeton, NJ: Princeton University Press, 2001): 58-77, for summaries.

36 Donnelly (2003): chs. 2-3.

37 See http://www1.umn.edu/humanrts/instree/cairodeclaration.html (accessed June 16, 2013).

38 See Donnelly (2003): chs. 3-8.

39 Beitz (2009): ch. 7.

${ }^{40}$ See e.g. Rawls (1999), Freeman (2006), and Reidy (2004).
} 
article, "Reconceptualizing Human Rights" 41 , I argued that these problems are due in large part to theorists and practitioners using the term "human rights" too coarsely. First, I argued that careful moral and semantic analysis reveal that the term "human right" refers simultaneously to two very different types moral entitlements - namely:

International human rights: the moral entitlements that all human beings have to coercive international protections.

Domestic human rights: the moral entitlements that all human beings have to coercive domestic protections (within their own state) but only non-coercive international promotion.

Second, I argued that by failing to explicitly distinguish between both types of entitlements, human rights theorists and practitioners have effectively treated two very different things as though they are one type of thing: "human rights." Finally, I argued that it is precisely this confusion - treating two very different types of moral entitlements as though they are one ("human rights") - that has led theorists and practitioners to disagree so wildly. For, I argued, both types of entitlement - domestic human rights and international human rights fundamentally pull in opposite directions. Because international human rights are moral entitlements to coercive international protection (up to and including military force), international human rights intuitively ought to be:

- Minimal international standards, which are

- Few in number, and

- Protections of some kind of particularly "urgent" or "fundamental" human interests or capacities.

${ }^{41}$ Arvan (2012). 
Domestic human rights, on the other hand - given that they are moral entitlements to coercive domestic protections above and beyond these basic international rights - should intuitively be:

- Non-minimal standards

- Many in number, and

- Protections of less urgent or fundamental human interests or capacities than international human rights.

This taxonomy thus explains why there has been so much theoretical and practical disagreement about human rights. Human rights theorists and practitioners have been unable to come to any agreement on whether "human rights" are (A) minimal or non-minimal standards, (B) whether they function to justify international coercion or not, (C) what human interests or capacities they should protect, and so on, because they - theorists and practitioners alike - have supposed themselves to be talking about a single, unified class of moral entitlements, "human rights", when in fact human rights are two very different types of moral entitlements.

Finally, my earlier article thus entails that a successful theory of human rights must be quite different than existing theories. Whereas existing theories attempt to give a single grand, unified account of "human rights", if my argument is correct (as I believe it to be), a proper theory of human rights must be a dual theory, one half of which explains and justifies,

A. International human rights: which coercive international protections all human beings are morally entitled to,

and the other half of which explains and justifies,

B. Domestic human rights: which coercive domestic protections all human beings are morally entitled to. 
It is only through giving such a dual theory that we can explain, persuasively and with proper philosophical clarity - effectively distinguishing between international and domestic human rights - precisely:

- What human rights are (i.e. what their practical or metaphysical nature is)

- How many of them there are

- What they are for (what role they are supposed to play in social-political practice)

- What human interests or capacities they are supposed to protect

- Who they impose duties upon

- What those duties are

- Etc.

However, while my earlier article reveals the source of the confusion that has plagued human rights theory and practice, and lays out the above roadmap for resolving it, it does not attempt to complete the project of providing a theory of both types of human right. The present paper aims to accomplish precisely this. It presents and defends the first dual theory of human rights, showing how the theory resolves many of the biggest philosophical and practice problems surrounding human rights.

$\S 1$ argues that international human rights - the moral entitlements that all human beings have to coercive international protection - are best understood in terms of protections of each human being's personhood, where this notion is understood roughly according to the "personhood model" that James Griffin defends in his recent book On Human Rights. Although I argue (following Griffin's many critics) that Griffin's theory of human rights is flawed - at least in part because it does not distinguish between the two types of human rights I distinguish between in my earlier article - I show in $§ 1$ that, after a few simple revisions, Griffin's concept of personhood provides a clearer and more persuasive moral justification of international 
human rights than any other potential justification, including all other existing justifications for human rights in the human rights literature. First, I show that alternative grounds for explaining and justifying international human rights - attempting to justify them in terms of "fundamental" or "urgent" human interests, "central human capabilities", or a "minimally decent human life" - cannot provide any kind of clear or persuasive distinction between domestic and international human rights. Second, I argue that if anything does provide a clear and persuasive justification of universal human moral entitlements to coercive international protections, it is each human being's moral entitlement to be treated as a human being, rather than as an animal or a mere object. Third, I argue that after a few important revisions, Griffin's personhood account provides a clear, compelling, cross-culturally acceptable account of precisely this: an account of what it is for people to be treated like human beings, and why coercive international force ought to be used when, and only when, people are not treated that way. Thus, I contend, Griffin's notion of personhood provides the clearest and most powerful justification of international human rights available. Finally, I argue that the account entails the following extremely "minimal" list of international human rights:

- Sufficient protection of life to ensure the ability to form and pursue a conception of a worthwhile life.

- Freedom from slavery and servitude.

- Sufficient protection of physical and mental well-being to ensure the ability to form and pursue a conception of a worthwhile life.

- Sufficient freedom of expression, association, occupation, religious practice, and movement to ensure the ability to form and pursue a conception of a worthwhile life.

- Sufficient minimum provisions of food, shelter, and medical care to ensure the ability to form and pursue a conception of a worthwhile life. 
$\S 2$ of this paper then teases out and defends this account's practical implications - implications which, I argue, while revisionary, would be a great improvement over existing international and foreign policies concerning human rights. I argue that although my account provides only an extremely minimal list of international human rights, thereby requiring significant revisions to existing standards of international and foreign policy - on my account, many nations currently treated as "human rights" violators (e.g. China, Iran, etc.) are no such thing, at least in terms of international human rights - these implications are compelling. For, I argue, existing international and foreign policy standards have not only permitted but encouraged repeated abuse of "human rights justifications" for harmful and imperialistic foreign policy actions. I contend that my theory not only clarifies the nature of these abuses, but also promises - were the account to become accepted and implemented in international discourse and practice - to prevent such abuses in the future.

$\S 3$ then argues, in order to stem the worry that this account of international human rights is "too minimal", that domestic human rights - the moral entitlements of all human beings to coercive domestic protections - include many more traditional "liberal" rights, including rights to freedom of expression, association, occupation, religious practice, and qualified right to democratic political participation. Following Thomas Christiano ${ }^{42}$, I argue that although on my account people only have very few international human rights, there are clear moral grounds for believing that people have very many domestic human rights - indeed, domestic human rights to minimally-egalitarian democratic rights and liberties, including freedom of speech, freedom of association, non-discrimination, and a right to vote.

Finally, §4 shows how this dual account of domestic and international human rights persuasively resolves the skepticism and disagreement about human rights discussed above.

42 T. Christiano, "An Instrumental Argument for a Human Right to Democracy", Philosophy and Public Affairs 39, no. 2, (2011): 142-176. 


\section{§1. A Theory of International Human Rights}

One of the most striking things about the human rights literature to date is just how little time theorists have spent addressing the issue of international coercion. Coercion, very roughly speaking, is to achieve something "by force or threat." 43 Of course, there is a great deal of disagreement in philosophy about what exactly this comes to. ${ }^{44}$ However, we need not settle these issues here. There is ample agreement about which types of actions are coercive in international and foreign policy: the use of military force and punitive economic sanctions are paradigm cases of international coercion. Accordingly, I propose that we move forward here by focusing on these paradigm cases. We can discuss less clear, "penumbral" cases elsewhere.

Here is a small but representative sample of how little international coercion has been discussed in human rights theory. In his widely discussed recent book, The Idea of Human Rights, Charles Beitz devotes a single page to the question of when human rights warrant coercive international enforcement, stating that coercion and military force are 'dramatic' and 'exceptional' means for enforcing human rights. ${ }^{45}$ Beitz never provides any clear analysis of which human rights warrant coercive international enforcement, when, or why. Similarly, in his book Making Sense of Human Rights, James Nickel devotes just two sentences to this issue, stating merely that, "Because enforcement efforts are costly and dangerous it is reasonable to restrict their use to the most severe human rights cases. These tend to be situations in which large numbers of people are being killed." 46 Similarly, Rawls devotes just two paragraphs to the issue in his The Law of Peoples, broadly stating that respect for human rights is sufficient to exclude coercion or, in 'grave' cases, military force (fair enough - but when is their violation

\footnotetext{
43 http://www.merriam-webster.com/dictionary/coercing (accessed on July 8, 2013).

${ }^{44}$ See e.g. S. Anderson, "Coercion", The Stanford Encyclopedia of Philosophy (Winter 2011 Edition), Edward N. Zalta (ed.), URL $=<$ http://plato.stanford.edu/archives/win2011/entries/coercion/>).

45 Beitz (2009): 39.

${ }^{46}$ Nickel (2007): 101.
} 
sufficient to warrant coercion and force?). ${ }^{47}$ Similarly, in his book, Justice, Legitimacy, and SelfDetermination, Allen Buchanan says little more of coercive international enforcement than that, "armed intervention may be needed as an ultimate sanction for the [human rights] principles I have proposed." 48

Why has the relationship between human rights and international coercion been so short and poorly investigated? The answer is simple. Because human rights theorists have treated human rights as one kind of thing ("human rights") - a thing to be understood in terms of a single justification (such as in terms of "urgent human interests", "a minimally decent human life", etc.) - these theorists have backed themselves into a corner where they lack sufficient conceptual and substantive resources to distinguish human rights that warrant coercive international interference (and explain when and why they do) from those that do not. Allow me to illustrate. Suppose one holds, as Buchanan, Nickel, and many others do, that human rights are protections of "a minimally decent human life." Then suppose one argues - as these theorists do - that human rights include all of the following things: rights to life and freedom from slavery, but also freedom of speech and association. ${ }^{49}$ Given that these theorists understand all of these "human rights" in terms of a single justification - in terms of a "minimally decent human life" - how can these theorists account for when, and why, some of the rights (e.g. the right to life) they assert might warrant coercive international intervention (up to and including force) whereas other human rights (e.g. the right to free speech) do not? Notice that they cannot say things like this: "Only the human right to life is necessary for a minimally decent life. That is why it justifies international force, but freedom of expression does not." No, since these theorists understand all human rights as having the same

\footnotetext{
${ }^{47}$ Rawls (1999): 79-80.

${ }^{48}$ Buchanan (2004): 442-3.

${ }^{49}$ Ibid: 129. Nickel (2007): 103.
} 
justification - a "minimally decent life" - they are simply left with no real conceptual or moral resources for justifying international force in some cases (life) but not others (free speech). All they can give are the kinds of hand-wavy, vague statements we have seen them give above: statements such as that particularly gross violations of human rights - such as the right to life are "serious enough" to justify international intervention but things like free speech "not serious enough" to do so. But these kinds of hand-wavy answers are morally and conceptually inadequate. If a theory of human rights should be able to do anything, it should be able to explain in a conceptually clear and morally compelling way, precisely when and why human rights entitle people to international coercive protection. This is fundamentally impossible, however, as long as theorists fail to explicitly distinguish what I have termed domestic and international human rights. Unless and until international human rights are explicitly distinguished from domestic ones, no clear conceptual and moral distinction between the two that is, no clear account of when and why people have human rights entitlements to coercive international intervention - can possibly be given. For the distinction between these two types of rights just is the moral and conceptual distinction between moral entitlements to coercive international intervention and mere moral entitlements to coercive domestic protection.

Now that we have my reconceptualization of human rights on offer, we are in a position to set these matters right. Instead of thinking about "human rights" under one giant heading as human rights theorists have done until now - let us break human rights theory down into its two proper parts - domestic and international human rights - focusing, first, on a very specific question: what is it about human beings - all of us, as human beings - that might entitle us to coercive international protections? If we can give a clear and convincing answer to this question, as I will now try to show we can do, we will, for the first time, have a clear and 
detailed theory of international human rights. We will then be in a proper position to properly discuss the other half of the equation: domestic human rights.

\section{§1.1. The Case for International Human Rights as Protections of Personhood}

The fundamental question at hand is this: what is it about us, as human beings, that could morally entitle us - all of us - to coercive international protections, up to and including military force? In what follows, I will defend the following argument:

1. Because international coercion, as a rule, carries very serious human costs, an adequate moral justification for universal human moral entitlements to coercive international protection (i.e. international human rights) should be as clear and immune from skepticism as possible in two respects:

a. The moral grounds themselves should be clear and immune from skepticism.

b. That those moral grounds justify international coercion should be clear and immune from skepticism.

2. Almost all existing moral justifications for human rights - e.g. "a minimally decent human life", "fundamental human interests", "basic human needs", etc. - fail on at least one of the above grounds (i.e. (a) and (b)).

3. The idea that all human beings are morally entitled to coercive international protections based on their personhood - as protections of the capacities that make us human - satisfies both (a) and (b).

4. Thus (from 1-3), international human rights should be understood as protections of personhood.

Let us begin with premise (1).

International force and coercion predictably cause serious harm to large numbers of people. The effects of military force are, of course, well known. Military force, as a rule, carries 
significant human casualties: death, dismemberment, and suffering. Punitive economic and political sanctions, however, also carry heavy costs as a rule. Economic sanctions, in particular, predictably cause severe human damage, up to and including death from lack of food or medical resources.50 For example, US economic sanctions on Iraq during the period of 19902003 are estimated to have caused between 100,000-500,000 innocent civilian deaths. ${ }^{51}$

Given these facts, there are obvious reasons to think that a moral justification for human entitlements to international coercive protection (i.e. international human rights) should be as clear and immune from skepticism as possible in two respects. First, if the international community is going to intervene coercively on individuals' behalf in ways that predictably lead to harm, the moral grounds given for such entitlements - that is, what the grounds themselves are - should be as clear and immune from skeptical worries as possible, or not plausibly objected to as hopelessly unclear or merely a matter of individual or cultural opinion. The reason for this is simple. Given how serious of a matter coercive international intervention is, we have every reason to avoid taking moral risks with people's lives and wellbeing. Truly adequate moral grounds for coercive international intervention should aim to be as clear and immune from skepticism as possible, precisely because such intervention carries large human costs. Second, it is not merely the moral grounds themselves that should be as clear and immune from skeptical worries as possible. We should want it to be clear that the moral grounds given are sufficient to morally justify human entitlements to international coercive protection. After all, even if a particular moral ground is clear and immune from

\footnotetext{
50 See e.g. J. Gordon, "A peaceful, silent, deadly remedy: The ethics of economic sanctions. Ethics \& International Affairs, 13(1), (1999): 123-142.

51 See e.g. 1999 UNICEF report, "Iraq Child and Maternity Mortality Surveys", http://www.fas.org/news/iraq/1999/08/990812-unicef.htm (accessed on June 17, 2013), and 2000 BBC report, "Child Death Rate Doubles in Iraq", http://news.bbc.co.uk/2/hi/health/763824.stm (accessed on June 17, 2013).
} 
skepticism in its own right (as a moral value), it may not be clear whether that ground is morally sufficient to justify international coercion.

Now, of course, I have been using two terms of art here: the terms "clear" and "immune from skeptical worries." But what exactly is it for a moral justification to be clear and immune from skeptical worries? Offhand, both would seem to be a matter of philosophical judgment. But this is not a problem: we can make comparative judgments on a case-by-case basis, seeing how different justifications for international coercion fare in terms of clarity and immunity from reasonable philosophical objections. I believe we will now see that one, and only one, moral justification for international human rights - understanding them as protections of personhood - clearly comes out on top on both counts.

Let us turn, then, to premise (2) in my argument - the premise that almost all proposed justifications for human rights fail as justifications for international human rights on at least one of the following two grounds:

a. The moral grounds given should be clear and immune from skepticism.

b. That those moral grounds justify international coercion should be clear and immune from skepticism.

I will now argue, first, that most of the moral grounds that human rights theorists have given for human rights fail on count (a): they are profoundly unclear and subject to reasonable skeptical worries. I will then argue that the few moral grounds given for human rights that arguably satisfy (a) fail on count (b): they fail to clearly and persuasively justify human entitlements to international coercion.

Let us begin with potential justifications for international human rights that fail on count (a). Here are some of the proposed justifications I have in mind: the idea that human rights are protections of "a minimally decent human life", "basic human needs", "fundamental 
human interests", or "urgent human interests." The fundamental problem with all of these proposals, I submit, is that they are fundamentally unclear and subject to natural, and reasonable, skeptical worries. Consider first the idea of a "minimally decent human life." What exactly is a "minimally decent human life"? It is not as though we have a minimally-decent-life stick to measure the quality of human lives similar to the manner in which a yard-stick measures yards. Perhaps there are a few things all reasonable people can agree are components of a "minimally decent human life." No reasonable person would presumably suggest that a person can live a "minimally decent life" if, say, they are dead. So, the "minimally decent life" approach might justify an international human right to life. But what about beyond this? Can a person live "a minimally decent life" without basic medical care? How is it to be decided one way or another? What about "adequate shelter"? Indigenous populations have lived without these things for thousands of years in some cases, and they might not say they live less than "minimally decent human lives." And yet, from a modern perspective, we might want to say that they do live "less than minimally decent lives." The fundamental problem here is this: the very notion of something's being "minimally decent" is plausibly a matter of individual and/or cultural judgment, and to whatever extent one attempts to make the idea precise, one can reasonably expect skeptical worries to be raised by otherwise reasonable dissenting parties.

Many other moral grounds that have been given for human rights face the same kind of problem. Charles Beitz argues, for example, that human rights are protections of "urgent human interests." But what makes a right urgent? Again, it is not as though we have an urgenthuman-interests stick to measure the matter, like a yard-stick, and people in different cultures may disagree significantly about what is and is not "urgent." Is basic medical care an urgent human interest? Some (or even many) of us in modern western societies might think so - yet 
members of an indigenous people who have lived without basic medical care for generations might think not.

Or consider the idea of "fundamental human interests." Here again we have the same problem. What human interests are "fundamental"? The religious Believer might well think that human beings have a fundamental interest in religious freedom. But what about the New Atheist who truly believes that religion itself is fundamentally responsible for many, or even most, of the world's evils? They may not think religious freedom is a fundamental human interest. Finally, consider the idea that human rights are protections of "basic human needs."52 Here again we have the same problem. Just like the notions of "a minimally decent life", "urgent interests", or "fundamental human interests", the notion of a "basic human need" seems essentially contestable. What one person might consider a "basic human need" another person might not. For instance, is basic modern medical care a human need? We might say yes, indigenous tribespeople might say no. Is religious freedom a basic human need? A Believer might say yes, an Atheist might say no.

Now, it might be suggested at this point that an objective account of needs can be given in terms of what we need to survive as human organisms: that no human being can expect to survive, for instance, without food or adequate shelter (though one surely can survive without freedom of religion). The problem with this sort of idea, however, is two-fold. First, if it is really meant that human beings cannot expect to survive without "adequate shelter", the claim is empirically false: indigenous peoples have often survived and flourished without anything remotely close to what we, in the modern world, would consider "adequate shelter" (such as a house). Second, the more we aim to understand human rights in terms of "objective" notions like biological survival, the less distinctively human the needs in question seem. After all,

52 Miller (2007): 179-181. 
biological survival doesn't make us distinctly human. All animals face the issue of survival or death. But we are manifestly not interested in our rights as biological organisms; we want to know which sorts of moral entitlements we have to coercive international protection as human beings. If we are to justify international human rights properly, we had better do it not in terms of our needs as organisms but rather in terms of something about us as human beings. But how might we do that? As we've just seen, the notion of distinctly human needs seems essentially contestable. So, understanding human rights in terms of any sort of "need" looks like a dead end.

The problem with existing moral grounds for human rights does not end here. Thus far we have focused on (a): the question of whether the moral grounds offered for human rights are themselves clear and immune to skepticism. But we are not only interested in the nature of various moral grounds considered in themselves: we are interested in a very specific question - namely, which moral grounds can provide a clear and convincing justification for human entitlements to international coercive protection (issue (b)). And here most existing grounds for human rights fare even worse. Consider first the lists of human rights that theorists have defended by reference to ideas such as "a minimally decent human life", "urgent human interests", and "central human capabilities." Allen Buchanan and James Nickel both defend human rights to freedom of expression and freedom of association as protections of "a minimally decent human life." But how clear is it, morally speaking, that violations of these rights entitle people to coercive international protection up to and including the use of military force? The answer, if Buchanan and Nickel are to be taken at their own words, is obvious: it is totally unclear. Buchanan and Nickel do not hold that violations of freedom of expression and freedom of association suffice to entitle people to coercive international protection. They are much more hand-wavy than this, suggesting (as I explained above) that only "especially severe" 
violations of human rights entitle people to coercive international intervention. So, the idea of a "minimally decent life" seems to fails on count (b): it is totally unclear when, or why, violations of rights "necessary for a minimally decent human life" might morally entitle people to coercive international protection.

Now consider another popular approach to justifying human rights that I think arguably satisfies count (a) - and so which I did not discuss above - but which clearly fails on count (b): the idea that human rights should be understood as protections of "central human capabilities." ${ }^{\prime 3}$ As I just indicated, I do think this type ground for human rights has the virtue of being, in itself, clear and immune from skepticism. Some things clearly are central human capabilities. As Nussbaum argues, all normally developed human beings plausibly have interests in being capable of the following: life, bodily health, bodily integrity, the use of their senses, imagination, and thought, emotional experience, practical reason, affiliation with others, engagement with nature, play, and having some control over their environment. But even if we grant all of this, the capabilities approach is fundamentally unable to address issue (b) adequately: namely, it cannot provide a clear justification immune from reasonable skeptical worries for human entitlements to international coercive protection. For example, proponents of the capability approach presumably do not believe that absence of play-time, or an inability to exercise imagination or engage with nature, morally entitle people to coercive economic sanctions or military intervention. But why not? On the capabilities approach, such things are central human capabilities. The answer, presumably, is this: proponents of the capabilities approach think that some central human capabilities (life? bodily integrity?) morally entitle people to coercive international protection, but other central human capabilities (play? imagination?) provide no such entitlement. But this is just to say that the

${ }^{53}$ Sen (1985), Nussbaum (2000). 
idea of central human capabilities is insufficient to explain what morally entitles human beings to coercive international protection. Some other clear and persuasive explanation must be given for why some central human capabilities morally entitle people to coercive international protection while others do not.

Now that we have seen the problems that most moral justifications run into in terms of serving as a clear and persuasive justification for international human rights, let us turn to the final premise in my argument: premise (3), the premise which says that personhood provides the clearest and most persuasive moral justification available for international human rights.

James Griffin's recent book On Human Rights has been widely critiqued on a number of grounds, but principally on the ground that Griffin never investigates in any detail what makes something a right to begin with. ${ }^{54}$ Still, despite its failures, I believe Griffin's book contains one very powerful insight: it provides - at least after some revisions - a maximally "objective", cross-culturally acceptable, and intuitively compelling account of human beings' moral entitlements to coercive international protection (i.e. our international human rights). What exactly is so objective, cross-culturally acceptable, and compelling about his account? Although Griffin does not distinguish between domestic and international human rights as we have, Griffin provides a theory of what it is for people to live, and be treated by others, as human beings. Griffin writes,

Human life is different from the life of other animals. We human beings have a conception of ourselves and of our past and future. We reflect and assess. We form pictures of what a good life would be - often, it is true, only on a small scale, but

\footnotetext{
${ }^{54}$ D. Reidy, "When Good Alone Isn't Good Enough: Examining Griffin's On Human Rights." Social Theory and Practice. 35(4), (2009): 623-647.
} 
occasionally also on a large scale. And we try to realize these pictures. This is what we mean by a distinctively human existence... 55

Setting aside the fact that some human beings (e.g. infants and the severely mentally disabled) lack these capacities - an issue we will return to later - Griffin's description of what it is to live a recognizably human life is surely correct. It is not "just a matter of opinion" whether what distinguishes human beings as such from other animals is our ability to consider our lives as a whole, reflect on them, and set and pursue goals based on those reflections. No, this is clearly what it is to be distinctly human, as opposed to a non-human animal or mere object. Further, if anything could intuitively morally entitle people, as human beings, to coercive international protection, the right to be treated like a human being surely fits the bill. It requires only a moment's reflection on historical cases - on cases where "we are sure" that people are entitled to coercive international intervention - to see how powerful this idea is. The fundamental moral problem with Nazi concentration camps is that they treated people like animals or mere objects. The Jews and other "undesirables" who were rounded up, gassed, or otherwise tortured and executed by the Nazis were entitled to coercive international protection because they were human beings who were not being treated like human beings. The same seems true of slavery. The problem with slavery - and the moral reason why slaves are intuitively morally entitled to have the international community intervene on their behalf - is that, no matter if they are "treated well" by their masters, they are not even being treated as human beings. Slaves, that is, anyone who are forced to work against their will, at the whim of a master, are human beings who are treated like animals.

This, in a nutshell, is what seems so powerful about Griffin's idea of personhood. In contrast to vague and contestable ideas such a "minimally decent human life", "dignity", and so

\footnotetext{
${ }^{55}$ Griffin (2007): 32-3.
} 
on, (A) we all have - in every culture on earth - an idea of what it is to treat people like human beings, and (B) if anything could clearly and objectively entitle us - as human beings - to coercive international protection, the fundamental right to be treated like a human being fits the bill. What could an international human right be if not a universal entitlement to be treated like a human being rather than an animal or mere object?

Finally, I want to submit that Griffin's notion of personhood is explanatorily more powerful than rival approaches to justifying human rights because it is the best way of explaining what it is about those other accounts that seem plausible to begin with. Consider a slave who is treated very well by his/her master: a slave who is not whipped, or beaten, or whatever. Set aside the question of how plausible or (un)common this case might be, and simple ask: would such a slave live a "minimally decent human life"? Most of us, I take it, want to say: no. But why? Such a slave, if s-/he were well-treated, might not live in pain. On the contrary, they might live a "happy" enough life. Why, then, do we want to say, despite this, that they don't live "a minimally decent human life"? One obvious answer is this: slavery is a life without human dignity. But what is human dignity? Griffin's notion of personhood, and only it, I submit, gives a particularly deep and compelling answer: a slave fails to live "a minimally decent human life" or a "life with human dignity" because they are not even being treated like a human being. In other words, it is only through Griffin's idea of personhood that we can explain what seems, intuitively, like "a minimally decent life", "human dignity", or "central human capabilities", etc. All of these ideas, to the extent that they have any moral pull on us, ultimately trace back to the idea that what makes us human, and what entitles us to coercive international protection, is our personhood: our abilities, qua human beings, to consider our lives as a whole, and make and pursue life plans on the basis of our own judgments about what makes for a good or decent human life. 
I submit, as such, that Griffin's personhood account - and only it - is capable of doing what any adequate theory or justification of international human rights should do: explain, in maximally objective terms, that no one can reasonably deny, when and why people are morally entitled to coercive international protections as human beings, "simply in virtue of being human."

\section{§1.2. Revising Griffin's Personhood Account}

In order to see this more fully, however - in order to see precisely how Griffin's idea of personhood provides the most compelling justification of international human rights available - we must take a much closer look at the notion of personhood, correct any errors or failures of clarity on Griffin's part, and then derive a final list of international human rights to "test" against our considered moral judgments (a common way of evaluating any moral or political proposal).

Griffin argues, again, that to treat people as human beings, we must respect their personhood: the thing that makes us distinctly human, namely, "our capacity to choose and to pursue our conception of a worthwhile life."56 Griffin then attempts to break down this capacity into three parts: autonomy, liberty, and minimal provision. Autonomy, very roughly, is the ability to choose a conception of a worthwhile life absent brainwashing, domination, manipulation, conformity, or false consciousness. ${ }^{57}$ Liberty, very roughly, is the ability to pursue a conception of a worthwhile life without hindrance in the form of force, coercion, or intimidation. ${ }^{58}$ Finally, minimal provision, very roughly, is having enough goods and services food, basic education, etc. - to be able to exercise autonomy and liberty.59

\footnotetext{
${ }^{56}$ Griffin (2007): 45.

57 Ibid: chapter 8.

58 Ibid: chapter 9.

${ }^{59}$ Ibid: chapter 2.
} 
Griffin attempts to derive human rights from each of these components of personhood considered individually. So, for instance, in Chapter 9, Griffin argues that the liberty component of personhood justifies a human right to free association - including "one or other form" of legally recognized civil unions for same-sex couples - but not (or so he implies) a human right to the same type of civil union (i.e. marriage). ${ }^{60}$ Why? Griffin's answer is essentially this: one cannot form and pursue a conception of a worthwhile life at all (i.e. be treated like a human being) if one has extremely restricted choices about those with whom one can associate, as would be the case if one had no human right to form legally recognized unions with individuals of one's choosing, regardless of gender identity. However, one can form and pursue a conception of a worthwhile life (i.e. be treated like a human being) even if one is not given equal opportunities, and even if one is discriminated against. ${ }^{61}$ Thus, while everyone has a right to some type of "civil union" or other, on Griffin's account, there is no human right to marriage. Human rights, on Griffin's account, are only rights to enjoy and exercise one's personhood, not fairness - and one can enjoy and exercise personhood without enjoying fully equal rights before the law. ${ }^{62}$

I would like to suggest that Griffin's splitting personhood into three components is more confusing than it is helpful. Instead of attempting to pin down autonomy, liberty, and minimal provision individually, and determine which human rights each component may or may not imply, I propose that Griffin's broader definition of personhood suffices - and indeed, provides a much clearer normative picture - of which international human rights people have, and why they have them. Here, after all, is Griffin's root idea: a person is treated as a human being just in case the capacity that makes us distinctly human - our capacity to develop and pursue a

\footnotetext{
${ }^{60}$ Ibid: 163.

61 Ibid: 196-201.
}

62 Ibid: 198-199. 
conception of a worthwhile life - is respected. I think we can get from this idea alone to a compelling list, and justification, of international human rights. Allow me to explain.

Contrast the following four sets of social and political conditions:

Society 1 (Rampant and indiscriminate murders and disappearances): as a matter of everyday life, citizens in this society live in daily fear of beings kidnapped or killed irrespective of their choices. A person, due to no particular decision of their own, may be kidnapped or murdered either at home, or at work, or anywhere else for that matter.

Society 2 (Command economy): no one has a choice in their occupation. Every child is forced to receive an education, and the state determines every individual's occupation on the basis of educational test scores.

Society 3 (Imprisonment or murder of political dissidents): in everyday life, people are more or less free to live their lives within the bounds of the law. They are generally free to choose their own occupation and associate with whomever they like - with just a few exceptions. No one is permitted by law to speak in favor of democracy, or against the Supreme Ruler. Anyone who runs afoul of these constraints may be detained indefinitely or executed for treason as a political dissident.

Society 4 (Unequal treatment on the basis of race or gender): in everyday life, women and racial minorities are more or less free to live their lives within the bounds of the law. They are free to choose their own occupation and associate with whomever they like with some significant constraints. Women are not permitted to operate vehicles without accompaniment by a male. Married women are not permitted to occupy a room 
alone with a man who is not their husband. Members of certain racial minorities are not permitted to attend the same schools or restaurants as members of the racial majority.

All four of these societies are unjust according to any mainstream liberal political theory. However, there is a clear, and intuitively morally momentous difference, between Societies $1 \& 2$ and Societies 3\&4. People in Societies 1\&2 are not treated like human beings. People in Society 1 are not free to develop and pursue a conception of a worthwhile life. Their capacity to develop and pursue a conception of a worthwhile life is at serious risk every single day of their lives. Any person who attempts to develop and pursue any conception of a worthwhile life may, on any given day, be murdered or kidnapped, thus thwarting their ability to pursue any such life at all. The same is true in Society 2 . No one in this society is given any choice of their occupation. They are forced by the state to spend their lives working in an occupation not of their own choosing.

Societies 3\&4, however, are very different. By Western eyes, both of these societies are profoundly unjust. And yet, however unjust they are, their citizens - even those who suffer injustice - are, on a day basis, treated as human beings; not as equal human beings, to be sure (men and women are treated unequally in Society 4), but at least as human beings: as beings capable of developing and pursuing a plan of a worthwhile life. Yes, there are significant constraints on which type of life people can pursue. Women and racial minorities in Society 4 are not permitted by law to do certain things, and may be punished severely if they try. Similarly, people in Society 3 may be punished, even with death, for speaking out against the government. But, for all that, people in both societies are still treated as human beings. A person in Society 3 is capable of, and permitted to, plan and pursue any one of a number of conceptions of a worthwhile life. There are only a few isolated exceptions: one is not allowed 
to speak out for democracy or against the Supreme Leader. Other than this, one can seek any occupation one wishes, associate with whomever one wishes - in short, develop and pursue a conception of a worthwhile life. Similarly, in Society 4, there are significant (and unjust) limitations. Women are not permitted to operate vehicles on their own or occupy rooms alone with men who are not their husbands. But still, despite this, women in this society have the ability to develop and pursue a conception of a worthwhile life. A woman in Society 3 can pursue higher education (or not), she can pursue an occupation (or not), and so on.

The moral difference between Societies $1 \& 2$ and Societies $3 \& 4$, in short, is enormous. Recall what international human rights are, according to my taxonomy. International human rights are moral entitlements to coercive international protection that all human beings have (simply in virtue of being human). As we saw earlier, if anything can clearly and persuasively justify human entitlements to coercive international protection, it is people not even being treated like human beings. Societies that imprison or execute political dissidents or treat women and minorities unjustly may indeed be grossly unjust, but for all that, they can (as we see in Societies 3\&4) treat their people like people. They may be worthy of international criticism or even condemnation - but military force or economic sanctions? If we believe that military force and other forms of international coercion should be reserved for the very worst injustices - as most human rights theorists already seem to think $\mathrm{k}^{63}$ - then intuitively this is precisely where we should draw the line: people are morally entitled to international coercion intervention when, and only when, they are not being treated as human beings.

Finally, I think our discussion of Societies 1-4 demarcates, much more clearly and persuasively than Griffin does himself, precisely which international human rights people have.

${ }^{63}$ See e.g. Beitz (2009): 39, Nickel (2007): 101, Rawls (1999): 79-80, and Buchanan (2004): 442-3. 
Griffin (who never distinguishes domestic and international human rights, according to my taxonomy) suggests that,

Out of the notion of personhood we can generate most of the conventional list of human rights. We have a right to life (without it, personhood is impossible), to security of person (for the same reason), to a voice in political decision (a key exercise of autonomy), to free expression, to assembly, and to a free press (without them, exercise of autonomy would be hollow), to worship (a key exercise of what one takes to be the point of life). It also generates, I should say (though this is hotly disputed), a positive freedom: namely, a right to basic education and minimum provision needed for existence as a person - something more, that is, than mere physical survival. It also generates a right not to be tortured, because, among its several evils, torture destroys one's capacity to decide and stick to a decision. And so on. ${ }^{64}$

I will now argue that if we stay true to Griffin's root notion of what personhood is - to what it is to treat people as human beings -- almost all of the above passage is quite wrong. His notion of personhood entails a much more minimal - but, I propose, entirely plausible - account of which international human rights people have.

\section{§1.3. From Personhood to a List of International Human Rights}

Griffin's conception of personhood, then, intuitively seems to provide the strongest grounds for justifying international human rights: the moral entitlements that all human beings have to coercive international protection simply in virtue of being human. The only question that remains is this: which international human rights, precisely, does Griffin's conception of personhood justify?

${ }^{64}$ Griffin (2007): 33. 
Consider once again Griffin's basic idea: that respect for each individual's person treating each person as a human being - is a matter of respecting each person's capacity to develop and pursue a conception of a worthwhile life. Griffin, as I noted above, thinks we can get "most of the familiar" list of human rights out of this: the rights to life, freedom from slavery and servitude, freedom of movement, freedom of association, freedom of expression, the right to a voice in political decisions, the right to a free press, etc. But wait: are all of these things truly necessary to respect the ability of individuals to develop and pursue a conception of a worthwhile life? The answer, quite simply, is no.

It is surely true that a person cannot develop and pursue a conception of a worthwhile life if they are dead, arbitrarily imprisoned for long periods of time, a slave, or subject to forced labor. But must a person have complete freedom of movement, association, or free speech to develop and pursue a conception of a worthwhile life? Surely not. Consider a state in which people are given a significant amount of freedom of expression, but in which some forms of speech are prohibited (for instance, speech favoring democracy or critical of the Supreme Leader). Is this really a situation in which people cannot develop or pursue a conception of a worthwhile life? No. It is only a situation in which people are coercively prevented from pursuing some conceptions of a worthwhile life: for instance, a conception which involves speaking out in favor of democracy or against the Supreme Leader. A person who is prevented from speaking in those ways may not be treated justly (if, for instance, we believe that domestic justice requires free speech). Nevertheless, they are still being treated like a human being. They are still given ample room to develop and pursue a conception of a worthwhile life. There are just some conceptions that are rendered off limits. Similarly, consider a person who is given no right to participate in political decisions, such as in a theocracy. A theocracy may be unjust. But still, does it fail to treat its citizens as human beings? It is hard to see how it does, at 
least if its laws permit them to develop and pursue worthwhile plans of life: permitting them to select their own occupations and other life choices.

It is very hard to see, in other words, how full freedom of movement, association, and expression, or the right to participate in political affairs, are necessary for people to be treated like human beings. In order to be treated like a human being - as someone who capable of developing and pursuing a conception of a worthwhile life - people must only have some minimal levels of freedom of movement, association, and expression, and need not have any right to participate in government. But now how much freedom of movement, association, and expression must people have, exactly, to be treated like human beings? Well, once a person is not a slave or subject to forced servitude, or severe physical or mental harm at the hands of another human being, a person is capable of developing and pursuing a conception of a worthwhile life. A person's society might place severe limits on the kinds of life such a person can live - it might not permit some people to serve in government, for instance, and may require them to live in a particular city of province - but, as long as the person is capable of developing and pursuing a conception of a worthwhile life of their own, the person is still treated like a human being. In other words: a person is treated like a human being just insofar as they are not faced with death, arbitrary imprisonment, slavery, or servitude. A life with comparatively few choices may not be a desirable human life, but still, provided one at least has some choices - as long as one does not suffer in daily fear of persecution, death, dismemberment, or servitude - one is treated as a human being.

The point here, I think, is a crucial one extending as far as the issue of life. Does Griffin's personhood account, properly understood, generate any kind of unlimited entitlement (i.e. human right) to life? No. For consider again a state that executes political dissidents. Such practices may be profoundly unjust, but does it fail to treat its citizens as human beings? No, 
provided it doesn't murder people wantonly, and provided its people don't live in constant fear of being kidnapped and executed in ordinary life. Such a state still respects its citizens human capacity to develop and pursue a conception of a worthwhile life. It just places certain types of actions - criticism of the government - entirely off limits and punishable by death. Political dissidents who speak out against the government have chosen, as human beings, to risk persecution and death. Their persecution may, again, be profoundly unjust (indeed, I think it is). But still, being unjust and failing to treat people as human beings are very different things. Injustice cries out for correction. Failure to treat people as human beings cries out for forcible international correction.

Finally, however, this justification of international human rights plausibly entails a principle of proportionality for coercive international intervention. Morally speaking, each and every person in the world has an equal claim to be treated as a human being in the minimal sense defended here. Accordingly, since (as we have seen) coercive international actions typically result in sub-human treatment - i.e. death as a result of military involvement or childhood mortality as a result of economic sanctions or embargo - international human rights are a universal human entitlement to coercive international intervention proportional to whatever violations of those rights occur. This is, intuitively, another reason why the US military invasion of Iraq violated international human rights. For, as brutal as Saddam Hussein's regime may have been on Iraqi citizens, the number of innocent deaths resulting from the US invasion and occupation of Iraq is, by all reports, far higher, and thus, disproportionate to whatever international human rights violations Hussein perpetrated in the first place. 
In conclusion, the following is, I contend, a correct list of international human rights rights that the international community ought to (and is permitted to) coercively enforce in proportion to the level of their violation:

- Sufficient protection of life so that people do not live in constant fear of death.

- Freedom from slavery and all forms of servitude.

- Minimal levels of freedom of movement, association, expression, and occupation such that people have some real capacity to develop and pursue a conception of a worthwhile life.

These, and these alone, are the rights that are necessary for people to enjoy to be treated like human beings. Consequently, it is their violation, and their violation alone, that warrants coercive international protection. This is, obviously, a very minimal list of international human rights - but, as we will now see, I believe it withstands reflective moral scrutiny.

\section{§2. Revisionary, but Compelling, Implications of this Theory of International Human}

\section{Rights}

Coercive international actions, from political and economic sanctions to outright military force, have been repeatedly used over the past several decades - most often, by the United States - in the name of "human rights." For example, the US has coercively imposed a commercial, economic, and financial embargo on the nation of Cuba ever since 1960 in response to Cuba's refusal to move toward "democratization and greater respect for human rights." 65 The US has also imposed coercive sanctions on China in response to the military crackdown on public protests and free speech in Tiananmen Square in 1989.66 And, of course, the US has not only imposed economic sanctions on Iraq from 1990 to the present, but also invaded Iraq militarily in 2003 and occupied Iraq until 2011. Although the US government initially justified the

65 The Cuban Democracy Act, 1992.

66 T. Lum, "Human Rights in China and U.S. Policy", Congressional Research Service (2011): 30, http://www.fas.org/sgp/crs/row/RL34729.pdf (accessed on June 25, 2013). 
invasion and occupation on the grounds that Saddam Hussein's regime was a threat to international peace and security due to allegations it had weapons of mass destruction, as time went on, and weapons of mass destruction are not found, many US politicians increasingly attempted to justify the war and occupation on human rights grounds, citing the history of violence the Hussein regime was known to have taken against its own citizens. ${ }^{67}$

Although coercive sanctions and military intervention have been repeatedly justified on "human rights" grounds, many people - not only social and political theorists, but the public at large - have been morally uncomfortable with many of these cases. Long-term US economic sanctions on Iraq, for example, have been estimated to have cost anywhere between 100- and 500-thousand lives. ${ }^{68}$ The 2003 invasion and subsequent occupation of Iraq, on other hand, is estimated to have cost anywhere between 600 and one million lives. ${ }^{69}$ The United States' embargo of Cuba has been continually criticized as unjust and disproportionate to actual state of life in Cuba, causing the Cuban people to suffer from lack of food, clean water, medicine, and even soap, resulting in medical crises and higher rates of serious infectious diseases. ${ }^{70}$ Indeed, the UN General Assembly has repeatedly passed resolutions from 1992 to the present protesting the US embargo of Cuba. Finally, US sanctions on China and Burma have been criticized as ineffective and failing to properly appreciate cultural differences. ${ }^{71}$ Indeed, some have argued that the deployment of economic sanctions has demonstrated a clear and

\footnotetext{
${ }^{67}$ http://www.turks.us/article.php?story=20030730114304428 (accessed on Aug 2, 2013).

$68 \quad$ See http://www.casi.org.uk/info/garfield/dr-garfield.html and http://web.archive.org/web/20030904174428/http://www.dailystar.com.lb/opinion/03_09_03_c.asp (both accessed on Aug 2, 2013).

${ }^{69} \mathrm{http}: / /$ web.mit.edu/humancostiraq/ (accessed on Aug 2, 2013).

${ }^{70}$ M. Malloy, "Economic Sanctions and Human Rights: A Delicate Balance." Human Rights Brief 3, no. 1 (1995).

${ }^{71}$ C. Wall, "Human Rights and Economic Sanctions: The New Imperialism", Fordham International Law Journal 22(2), (1998): article 7.
} 
consistent kind of moral and cultural imperialism that is insensitive to the actual needs and quality of life of people living in "human rights violating" regimes. ${ }^{72}$

The reason, in short, why people are often morally uncomfortable with the use of sanctions and military force on human rights grounds is simple. As unjust as places like Cuba or China may be, and as oppressive as Saddam Hussein's regime was in Iraq prior to 2003, the human costs of coercive international actions - from sanctions to military force - seem disproportionate to the actual human situation in those regimes. For the simple facts are these. Although the average Cuban, Chinese, or Iraqi citizen may not enjoy the "human rights" codified in the UDHR or existing human rights covenants, on a day to day basis people in those nations have still been able to live recognizably human lives, and are treated on a day-to-day basis like human beings, not mere animals. The average Iraqi citizen did, in the Hussein regime, have to worry about being kidnapped or executed for certain kinds of speech - but still, as long as they did not behave in those ways, they could go about everyday human life in relative peace: they could have families, hold jobs, etc. The same is true in present-day China and Cuba. Although both nations' governments violate numerous UDHR articles and human rights covenants, Chinese and Cuban citizens still live recognizably human lives, and are treated as human beings, on a day-to-day basis. For although their citizens do not enjoy anything remotely like freedom of speech, expression, or religion, in conformity with existing human rights standards, their citizens do get to do all of the things that make a human life a human life: they can hold jobs, have families, have friends and acquaintances, and so on. In all of these places, however unjust their governments may be by Western standards, people still enjoy the basic human capacity that Griffin's account draws our attention: the distinctly human capacity to develop and pursue a conception of a worthwhile life. Yes, these governments set limits - sometimes quite

72 Ibid. 
extensive limit - on the kind of life their citizens are permitted to live; but setting limits on a person's choices is still consistent with treating them like a human being rather than an animal.

This is intuitively what is wrong with the imposition of coercive sanctions or military force on citizens in places like Cuba, China, or Iraq. Mere injustices - even severe injustices violating existing "human rights" standards - are not severe enough to morally justify international force or coercion. People are morally entitled to coercive international action when, and only when, they are treated so badly that they do not even live recognizably human lives, such as when people are being enslaved, exterminated, or terrorized by their government to such an extent that they cannot go about their daily lives developing and pursuing a conception of a worthwhile life. The theory of international human rights I have developed and defended here is the only theory that provides a detailed, and compelling, account of why this is. When people are treated like animals, or mere objects - when they cannot even go about their daily lives in peace, developing and pursuing a conception of a worthwhile life, due government terrorism, genocide, etc. - the rest of us are all morally required, as fellow human beings, to ensure that our governments take coercive actions, up to and including military force, to prevent and protect people from such abuses.

\section{§3. From International Human Rights to Domestic Human Rights}

Now that we have an account of international human rights - one that specifies, in far more detail and clarity than any existing theory, which moral entitlements all human beings have to international coercive protection - we need to turn to the second class of human rights I have distinguished:

Domestic human rights: the moral entitlements that all human beings have to coercive domestic protections (within their own state) but only non-coercive international promotion. 
Here, I believe, our task is much easier. Non-liberal/democratic domestic social and political conditions can treat people as human beings, in the sense given by Griffin's (suitably revised) personhood account. A person can have sufficient protections of their life, freedom of movement, association, religion, etc. in order to develop and pursue a conception of a worthwhile life - that is, they can be treated like a human being - without anything remotely like liberal-democratic social-political structures in place. Indeed, as we have seen - much to the surprise of many, I expect - even a tyrannical regime can treat its citizens as human beings. For instance, as bad as Saddam Hussein's regime in Iraq was prior to 2003 - where political dissidents were executed, etc. - people on a daily basis were still treated like human beings. They could go to work, form families, have friends, enjoy free time, and so on. The Hussein regime violated its citizens international human rights - but did so particularly severely - only on relatively rare occasions: such as when Hussein gassed Iraqi Kurds. While the account of international human rights defended here implies that the Iraqi people have human rights to coercive international protection against these kinds of atrocities, it does not imply a warrant to the kinds of standing coercive international measures - such as long-term economic sanctions - the US and its allies imposed on Iraq for decades.

However, although minimally liberal-democratic social and political conditions may not be the only way to protect basic (or what I am calling international) human rights, there are good reasons to believe that what Thomas Christiano refers to as minimally egalitarian democratic conditions are the most reliable domestic instrument for ensuring that those rights are consistently protected..$^{73}$ According to Christiano,

By minimally egalitarian democracy, I mean a democracy that has a formal or informal constitutional structure which ensures that persons are able to participate as equals in

${ }^{73}$ Christiano (2011). 
the collective decision making of their political society. It can be more precisely characterized in terms of the following three conditions: (1) Persons have formally equal votes that are effective in the aggregate in determining who is in power, the normal result of which is a high level of participation of the populace in the electoral process. (2) Persons have equal opportunities to run for office, to determine the agenda of decision making, and to influence the processes of deliberation. Individuals are free to organize political parties and interest group associations without legal impediment or fear of serious violence, and they are free to abandon their previous political associations. They have freedom of expression at least regarding political matters. In such a society, there is normally robust competition among parties and a variety of political parties that have a significant presence in the legislature. (3) Such a society also acts in accordance with the rule of law and supports an independent judiciary that acts as a check on executive power. ${ }^{74}$

A minimally egalitarian democracy, in other words, protects many, if not all, of the rights and liberties enumerated in the Universal Declaration of Human Rights. A minimally egalitarian democracy gives everyone minimally egalitarian rights to freedom of association, expression, equal opportunity (in politics), and rule of law.

Christiano's argument for these rights qualifying as what I call "domestic human rights" is simple. Although illiberal/undemocratic societies can protect the kinds of especially vital human interests that I believe should fall under the heading of international human rights, only minimally egalitarian democracies reliably succeed in protecting those rights, whereas illiberal/undemocratic societies reliably fail. Accordingly, although there is no sufficient reason to consider Christiano's minimally egalitarian liberal-democratic rights to be international

\footnotetext{
${ }^{74}$ Ibid: 146.
} 
human rights - for, again, illiberal/undemocratic societies can respect those minimal rights minimally egalitarian democratic rights should qualify as domestic human rights: as entitlements to coercive domestic protections that all human beings have simply in virtue of being human - simply because those domestic rights are the best domestic protections of the international human rights that all people have simply in virtue of being human.

\section{§3.2. The Plausibility of the Theory of Domestic Human Rights}

Just as I have maintained that the very minimal account of international human rights I have defended is very plausible, so too, I maintain, is this account of domestic rights. Once we admit that people have (basic) international rights - rights to be treated like human beings that entitle people to coercive international protections - the question of which domestic people have simply in virtue of being human is a simple empirical one. Because people are internationally entitled to be treated like human beings, they should be domestically entitled to whatever type of government most reliably protects those very rights. And, if Christiano is correct, minimally liberal-democratic conditions are the most reliable in this regard. Thus, although the Universal of Declaration of Human Rights is, on my account, radically incorrect as an account of international human rights, it is arguably broadly correct as an account of domestic human rights.

\section{§4. Human Rights Disagreement and Skepticism Addressed}

Let us now return to the areas of extreme disagreement and skepticism about human rights discussed at the outset of this paper. We saw that there is immense disagreement over:

- What human rights are (i.e. what their practical or metaphysical nature is)

- How many of them there are

- What they are for (what role they are supposed to play in social-political practice)

- What human interests or capacities they are supposed to protect 
- Who they impose duties upon

- What those duties are

We now have a clear and compelling answer to each question. Here is what human rights are:

International human rights are the moral entitlements that all human beings have to coercive international protection.

Domestic human rights are the moral entitlements that all human beings have to coercive domestic protections.

Next, here is how many there are. There are few international human rights. There are only international human rights to:

- Sufficient protection of life to ensure the ability to form and pursue a conception of a worthwhile life.

- Freedom from slavery and servitude.

- Sufficient protection of physical and mental well-being to ensure the ability to form and pursue a conception of a worthwhile life.

- Sufficient freedom of expression, association, occupation, religious practice, and movement to ensure the ability to form and pursue a conception of a worthwhile life.

- Sufficient minimum provisions of food, shelter, and medical care to ensure the ability to form and pursue a conception of a worthwhile life.

However, there are many domestic human rights. Specifically, there are domestic human rights to minimally egalitarian democratic rights and liberties, including:

- Minimally egalitarian rights to freedom of movement, association, expression, and religion.

- A democratic right to vote.

- $\quad$ The right to a fair trial by jury. 
- Etc.

Next, these accounts specify precisely what human rights are "for." International human rights are to function as minimal international standards to justify coercive international action ranging from sanctions to military force. Domestic human rights, on the other hand, are to function as standards of aspiration or good government that all human beings are domestically entitled to.

Next, these accounts provide a compelling analysis of which human interests and capacities each type of right functions to protect. International human rights exist to ensure that all human beings are treated like human beings - as creatures capable of developing and pursuing a conception of worthwhile human life - as opposed to mere animals or objects. Domestic human rights, on the other hand, are entitlements to the optimal social-political structures for ensuring that people are treated like human beings: namely, free and equal treatment.

Next, these accounts tell us precisely who human rights impose which duties upon, what those duties are, and why. International human rights impose duties upon us all, as members of a global community. When people are not being treated as human beings - when their international human rights are violated - we are all, intuitively, under an obligation to ensure that our governments act on our behalf to prevent or halt such violations. We are all, intuitively, under an obligation to ensure that people are treated like human beings. Domestic human rights, on the other hand, are very different. Because they are the best mechanism for ensuring that people are treated like human beings, we are all presumably obligated to ensure that our governments non-coercively promote respect for them abroad. However, domestic human rights do not function to warrant coercive international interference. They are 
universal human entitlements that all human beings have against their own citizens and governments.

\section{Conclusion}

The new theory of human rights defended here is admittedly provocative. While the theory of international human rights defended is extremely minimal - holding that coercive international action on behalf of human rights is warranted when, and only when, people are treated on a daily basis like animals rather than human beings (which is rarely the case) - the theory of domestic human rights defended is very broad: ascribing to everyone universal domestic entitlements to minimally egalitarian-democratic rights and liberties. Yet, however provocative the theory defended here is, I contend that it is compelling and resolves just about all of the disagreements and skeptical worries there have been about human rights. It is compelling because the grounds it gives for both types of human right are compelling. International force is intuitively justified when, and only when, people are not treated like human beings. Coercive domestic force, on the other hand, ought to provide people with the best instruments to ensure that people are treated like human beings. The theory provided here encompasses both of these very intuitive ideas. Finally, it not only encompasses these ideas, but uses them to clarify, clearly and intuitively, precisely:

- What human rights are (i.e. what their practical or metaphysical nature is)

- How many of them there are

- What they are for (what role they are supposed to play in social-political practice)

- What human interests or capacities they are supposed to protect

- Who they impose duties upon, and

- What those duties are. 
In short: human rights theory and practice have been stuck in a rut - but we have now found a clear and compelling way out.

University of Tampa 